\title{
PENGARUH PENGAWASAN DAN KOMUNIKASI TERHADAP KINERJA PEGAWAI PADA KANTOR UNIT PELAKSANA TEKNIS IRIGASI MUSI RAWAS DINAS PEKERJAAN UMUM PENGAIRAN KABUPATEN MUSI RAWAS
}

\author{
Purna Irawan \\ Institut Agama Islam Al Azhaar Lubuklinggau
}

\begin{abstract}
ABSTRAK
Pengaruh Pengawasan dan Komunikasi terhadap Kinerja Pegawai pada Kantor Unit Pelaksana Teknis Irigasi Musi Rawas Dinas Pekerjaan Umum Pengairan Kabupaten Musi Rawas. Penelitian ini bertujuan untuk mengetahui adanya Pengaruh Pengawasan dan Komunikasi secara bersama-sama terhadap Kinerja Pegawai. Adapun Populasi dalam penelitian ini yaitu 149 orang pegawai dan banyaknya jumlah sampel dalam penelitian ini yaitu sebanyak 37 orang pegawai. Adapun teknik sampling yang digunakan dalam penelitian ini yaitu teknik sampling Purposive. Teknik pengumpulan data menggunakan kuesioner (angket) yang akan diuji cobakan terlebih dahulu dengan menggunakan uji validitas dan uji reliabelitas. Teknik analisis data ini menggunakan uji asumsi klasik ( uji normalitas, uji multikolinieritas, uji heteroskedastisitas,uji autokorelasi dan uji liniearitas), regresi linear berganda, koefisien korelasi,dan uji F. Dimana peneliti ini menggunakan bantuan program SPSS versi 20.

Hasil dari analisis regresiini akan memperoleh persamaan: $\mathrm{Y}=-1,214+$ $0,561 \mathrm{X}_{1}+0,681 \mathrm{X}_{2}$, yang artinya kinerja pegawai berpengaruh terhadap Pengawasan dan Komunikasi pegawai. Hasil dari analisis regresi ini akan mendapatkan nilai koefisien korelasi $(\mathrm{R}=0,896)$ atau sebesar $(89,6 \%)$ dan nilai koefisien determinasi $\left(\mathrm{R}^{2}=0,803\right)$ atau sebesar $(80,3 \%)$. Hasil ini berarti $(80,3 \%)$ variabel kinerja pegawai ini akan dipengaruhi oleh variabel Pengawasan dan Komunikasi. Hasil akhirnya sebesar $(19,7 \%)$ digambarkan oleh variabel lain, seperti pendidikan, pelatihan, pengalaman kerja, kepemimpinan, komunikasidan disiplin kerja. Kesimpulannya adalah: Pengawasan dan Komunikasi secara bersama-sama berpengaruh signifikan terhadap kinerja pegawai Kantor Unit Pelaksana Teknis Irigasi Musi Rawas Dinas Pekerjaan Umum Pengairan Kabupaten Musi Rawas. Dari hasil ini membuktikan hasil uji $\mathrm{F}$ yang diperoleh

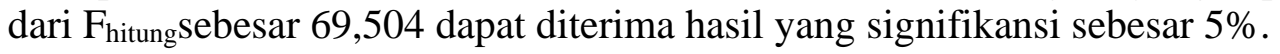

Kata Kunci ; Pengawasan, komunikasi, Kinerja 


\section{Latar Belakang}

Perkantoran Unit Pelaksan Teknis Irigasi Musi Rawas pada Dinas pekerjaan umun Pengairan Kabupaten Musi Rawas yang merupakan instansi di lingkungan Pemerintahan Kabupaten Musi Rawas. perkantoran Unit Pelaksana Teknis Irigasi Musi.

Rawas merupakan unsur pelaksana sebagian kegiatan teknis operasional atau kegiatan teknis penunjang Dinas Pekerjaan Umum Pengairan (DPUP). kantor Unit Pelaksana Teknis sebagaimana di pimpin oleh Kepala Unit Pelaksana Teknis Irigasi ini berkedudukan dibawah dan akan bertanggung jawab kepada Kepala Dinas, di dalam pelaksanaan tugasnya secara operasional berkoordinasi dengan Instansi terkait, dan secara administrative dikoordinasikan oleh Sekretaris Dinas.

Perkantor Unit Pelaksana Teknis Irigasi Musi Rawas Pada Dinas pekerjaan Umum Pengairan Musi Rawas adanya pemasalahan, pengawasan terkesan hanya formalitas saja, dalam pelaksanaan pekerjaan sering terjadi penyimpangan-penyimpangan, dan kebijakan yang akan diambil terkait dengan perbaikan penyimpangan- penyimpangan ini hanya akan bersifat formalitas saja, dan hasil pengawasan yang dilakukan jarang sekali dilakukan evaluasi untuk menghindari penyimpangan dimasa yang akan datang. Pengawasan dari pimpinan yang dirasakan kurang, terlihat dari seringnya pegawai menunda dan melalaikan pekerjaan yang telah diberikan tanggung jawabnya kepada pegawai yang bersangkutan.

Komunikasi yang akan terjadi dikegiatan pelaksanaan ini kurang berjalan dengan maksimal, hasil ini dapat dilihat, antar pegawai yang jarang sekali terjadi percakapan yang hangat, pegawai bekerja secara individu. Belum terjalinnya interaksi sosial antar pegawai, tidak adanya keterbukaan antar pegawai, kurangnya rasa saling mendukung satu dengan yang lainnya, sedikitnya waktu yang digunakan oleh pimpinan untuk berdiskusi oleh para bawahan dalam hal pekerjaan masing-masing.

Selanjutnya hasil dari keahlian yang dimiliki para pegawai di semua kegiatan pelaksanaan masih kurang cukup memadai, hal ini di karenakan sedikitnya pegawai yang tidak memahami dan mnguasai bidang kerjanya, dan 
juga tidak memiliki pengalaman yang cukup untuk melakukan pekerjaannya, masih rendahnya tingkat pendidikan yang di miliki oleh pegawai, dan rendahnya keahlian- keahlian yang di miliki oleh pegawai dibidang pengolahan informasi.

Hasil dari uraian-uraian, maka akan dilakukan penelitian dengan judul “ PENGARUH PENGAWASAN DAN KOMUNIKASI TERHADAP KINERJAPEGAWAI PADA KANTOR UNIT PELAKSANA TEKNIS IRIGASI MUSI RAWAS DINAS PEKERJAAN UMUM PENGAIRAN KABUPATEN MUSI RAWAS"

\section{Rumusan Masalah}

Bagaimana pengaruh Pengawasan dan Komunikasi terhadap kinerja pegawai pada Kantor Unit Pelaksana Teknis Irigasi Musi Rawas Dinas Pekerjaan Umum Pengairan Kabupaten Musi Rawas?

\section{Tujuan Penelitian}

Bagaimana besarnya pengaruh Pengawasan dan Komunikasi terhadap kinerja pegawai pada Kantor Unit Pelaksana Teknis Irigasi Musi Rawas Dinas Pekerjaan Umum Pengairan Kabupaten Musi Rawas.

\section{Manfaat Penelitian}

Hasil dari penelitian ini dapat di jadikan masukan bagi pengembangan ilmu di bidang Manajemen Sumber Daya Manusia dan juga dapat dijadikan sebagai salah satu bahan bacaan bagi peneliti selanjutnya. Informasi ini dapat di gunakan oleh peneliti sebagai referensi kepada Kepala kantor Unit Pelaksana Teknis irigasi Musi Rawas Dinas Pekerjaan Umum Pengairan Kabupaten Musi Rawas, yang akan mempengaruhi dari Pengawasan dan Komunikasi dalam meningkatkan kinerja pegawai. 


\section{TINJAUAN PUSTAKA}

\section{Kinerja}

Definisi kinerja berasal dari kata performance. Ada juga yang mengartikan sebagai performance sebagai hasil kerja atau prestasi kerja. Namun, sebenarnya kinerja sendiri mempunyai arti yang sangat luas, bukan hanya hasil kerja, tetapi termasuk bagaimana proses kerja berlangsung (Wibowo 2013, h. 7). Suprihanto (dalam jurnal Endang Dwiningsih, 2011) definisi dari kata kinerja yaitu hasil kerja selama periode tertentu dibandingkan dengan berbagai kemungkinan, seperti standar, target sasaran atau kriteria yang telah disepakati bersama.

\section{Faktor-faktor Yang Mempengaruhi Kinerja}

Adapun Factor-faktor yang dapat mempengaruhi kinerja, antara lain dikemukakan Armstrong dan Baron (dalam wibowo 2013, h . 100) yaitu diantaranya:

a. Personal factors, dapat ditunjukkan oleh tingkat keterampilan yang dikerjakan, kompetensi yang dimiliki, motivasi kerja, dan komitmen individu.

b. Leadership factors, dapat ditentukan oleh kualitas kerja dorongan, bimbingan, dan dukungan yang dilakukan manajer dan team leader.

c. Team factors, dapat ditunjukkan oleh kualitas dukungan yang diberikan oleh rekan sekerja dengan maksud untuk mencapai suatu tujuan.

\section{Pengawasan}

Definisi pengawasan kata lainnya manajemen diartikan sebagai salah satu kegiatan pengamatan dan penilaian secara berkesinambungan terhadap suatu objek kegiatan dengan menggunakan metode-metode, suatu alat, dan aturanaturan tertentu untuk menjamin kesesuaian pelaksanaannya dengan rencana dan kebijakan yang telah ditetapkan, Andrian, (2010, h. 262). Menurut Yosa (2010) pengawasan merupakan suatu proses dalam menetapkan ukuran kinerja dan pengambilan tindakan yang dapat mendukung pencapaian hasil yang di harapkan sesuai dengan kinerja yang telah ditetapkan 


\section{Komunikasi}

Kita sering sekali mendengar istilah kata Komunikasi (Bahasa Inggris : communication) yang mempunyai arti yaitu proses penyampaian makna dari satu entitas atau kelompok kekelompol lainnya melalui penggunaan tanda, symbol, dan aturan semiotika yang di pahami bersama. Menurut asal katanya (etimologi), istilah kata komunikasi berasal dari bahasa latin, yaitu communis, yang berarti sama (common). Dari kata communis inilah berubah menjadi kata kerja kommunicare, yang bearti menyebarkan atau memberitahukan maksud tujuan. Jadi menurut asal katanya, komunikasi bearti menyebarkan atau memberitahukan informasi kepada pihak lain guna mendapatkan pengertian yang sama, (wursanto 2005, h. 153). Menurutpara ahli antara lain : Elliot mengatakan (dalam Wursanto 2005, h. 153) komunikasi adalah penyampaian berbagai macam perasaan, sikap dan kehendak, baik secara langsung maupun tidak langsung.

\section{Kerangka Pemikiran}

\section{Pengawasan (X 1)}

\section{Indikator :}

1. Orientasi rencana

2. Orientasi hasil

3. Cepat dorientasi pengecualian

4. Menyeluruh

5. Akirat

6. Realistik

7. Adil

8. Dapat dimengerti

9. Tepat waktu

10. Efektif Biaya

11. Longgar

Silahi, (dalam jurnal,pramudya, 2013)

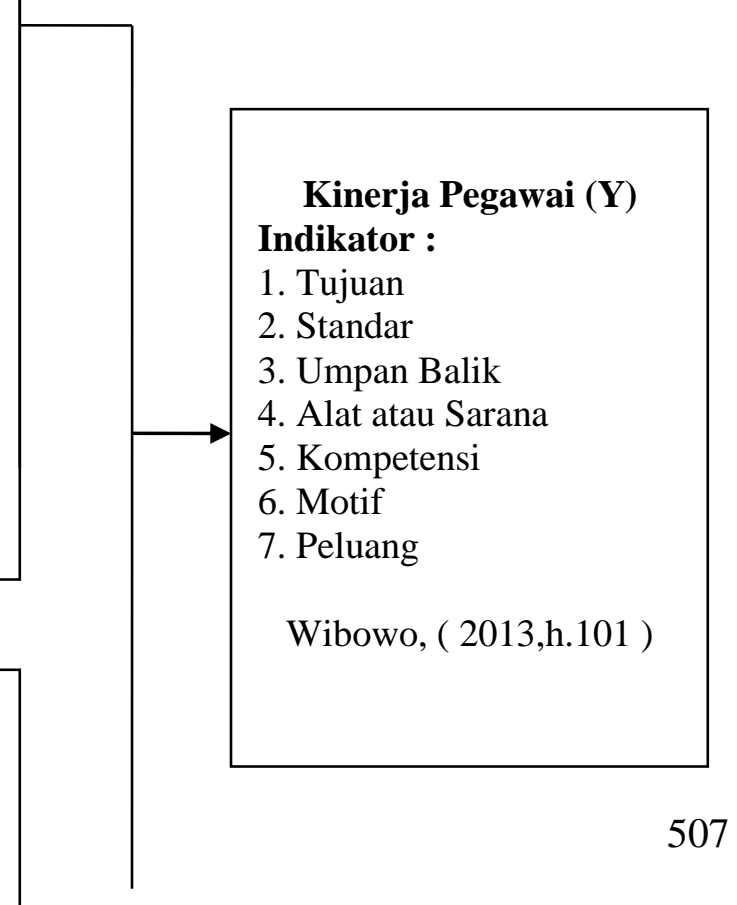

Indikator :

Komunikasi (X 2)

1. Pemahaman atau memahami

2. kesenangan atau kegemaran

3.Berpengaruh pada sikap

4. Adanya hubungan yang makin 
Gambar : Kerangka berpikir Pengaruh Pengawasan dan Komunikasi terhadap kinerja pegawai pada kantor Unit Pelaksana Teknis Irigasi Musi Rawas Dinas Pekerjaan Umum Pengairan Kabupaten Musi Rawas. 


\section{Hipotesis Penelitian.}

Hipotesis yang berarti hasil dari jawaban sementara terhadap rumusan masalah penelitian, dimana rumusan masalah penelitian telah dinyatakan dalam bentuk pertanyaan (Sugiyono 2012, h. 64). Adapun arti hipotesis dalam penelitian ini yakni diduga ada pengaruh signifikan antara pengawasan dan komunikasi terhadap kinerja pegawai pada Kantor Unit Pelaksan Teknis Irigasi Musi Rawas Dinas Pekerjaan Umum Pengairan Kabupaten Musi Rawas.

\section{METODOLOGI PENELITIAN}

\section{Variabel Penelitian dan Definisi Operasional Variabel}

\section{Variabel Penelitian}

Operasional Variabel, Definisi Variabel, Indikator dan Skala Penelitian

\begin{tabular}{|c|c|c|c|c|}
\hline No & Variabel & Pengertian & Indikator & Skala \\
\hline 1 & $\begin{array}{l}\text { Pengawasan } \\
\text { ( X } 1 \text { ) }\end{array}$ & $\begin{array}{l}\text { Pengawasan merupakan } \\
\text { suatu kegiatan dari } \\
\text { pengamatan dan penilaian } \\
\text { secara berkesinambungan } \\
\text { terhadap suatu objek kegiatan } \\
\text { dengan menggunakan } \\
\text { metode, alat, dan aturan } \\
\text { tertentu untuk menjamnin } \\
\text { kesesuaian pelaksanaannya } \\
\text { dengan rencana dan } \\
\text { kebijakan yang telah di } \\
\text { tetapkan, Sutedi, }(\mathbf{2 0 1 0}, \mathbf{h} . \\
\mathbf{2 6 2} \text { ) }\end{array}$ & $\begin{array}{l}\text { 1. Orientasi rencana } \\
\text { 2. Orientasi hasil } \\
\text { 3.Cepat dan } \\
\quad \text { orientasi } \\
\text { 4. Menyeluruh } \\
\text { 5.Akirat } \\
\text { 6. Realistik } \\
\text { 7. Adil } \\
\text { 8. Dapat dimengerti } \\
\text { 9. Tepat waktu } \\
\text { 10. Efektif biaya } \\
\text { 11. Longgar } \\
\text { Silahi, (dalam } \\
\text { jurnal } \\
\text { Pramudya, 2013) }\end{array}$ & Ordinal \\
\hline 2 & $\begin{array}{l}\text { Komunikasi } \\
\text { ( X 2 ) }\end{array}$ & $\begin{array}{l}\text { Komunikasi merupakan } \\
\text { suatu proses penyampaian } \\
\text { informasi dari satu pihak } \\
\text { kepada lain untuk } \\
\text { mendapatkan saling } \\
\text { pengertian atau timbale balik, } \\
\text { Wursanto, ( 2005, h. 153 ) }\end{array}$ & $\begin{array}{l}\text { 1.Pemahaman atau } \\
\text { memahami } \\
\text { 2.kesenangan atau } \\
\text { kegemaran } \\
\text { 3.Pengaruh pada } \\
\text { sikap } \\
\text { 4. Adanya } \\
\text { hubungan yang } \\
\text { makin baik } \\
\text { derafitria. } \\
\text { Wordpress. } \\
\text { Com.2012 }\end{array}$ & Ordinal \\
\hline
\end{tabular}




\begin{tabular}{|l|l|l|l|l|}
\hline 3 & Kinerja (Y) & Kinerja yaitu hasil dari & 1. Tujuan / maksud & Ordinal \\
& & pekerjaan yang mempunyai & 2. Standar \\
& & hubungan kuat antara satu & 3. Umpan balik & \\
& & dengan yang lain dengan & 4. Alat atau Sarana & \\
& & tujuan strategis organisasi, & 5. kompetensi & \\
& & kepuasan konsumen, dan & 6. Motif / bentuk & \\
& memberikan kontribusi pada & 7. Peluang & \\
& ekonomi, Armstrong dan & Wibowo, (2013, & \\
& Baron dalam ( & h. 102 ) & \\
& Wibowo,2013, h. 7) & & \\
& &
\end{tabular}

\section{Populasi dan Sampel}

Populasi merupakan suatu wilayah generalisasi yang terdiri dari obyek/subyek yang mempunyai kualitas dan karakteristik tertentu yang diterapkan oleh peneliti untuk dipelajari dan kemudian ditarik kesimpulan hasilnya (Sugiyono 2012, h. 80). Populasi yang di maksud dalam penelitian ini yaitu merupakan seluruh pegawai Kantor Unit Pelaksana Teknis Irigasi Musi Rawas Dinas Pekerjaan Umum Pengairan Kabupaten Musi Rawas yang berjumlah 149 pegawai (responden). Sampel merupakan bagian dari jumlah dan karakteristik yang dimiliki oleh populasi tersebut (Sugiyono 2010, h.81). Menurut Arikunto ( 2006, h. 134 ) apabila subyeknya kurang dari 100, lebih baik diambil semua sehingga penelitiannya merupakan penelitian populasi. Tetapi jika subyeknya lebih dari 100, dapat diambil antara 10 - $15 \%$ atau 20 - $25 \%$ atau lebih. Di dalam penelitian ini, para peneliti mengambil sampel sebanyak $25 \%$ dari 149 responden. Jadi peneliti hanya mengambil sampel 37 responden. Teknik sampling menggunakan Purposive sample maksudnya teknik pengambilan sampel melainkan mengambil dengan cara subyek bukan didasarkan atas strata, random, atau daerah tetapi didasarkan atas tujuan tertentu dan karena adanya beberapa pertimbangan, misalnya alasan keterbatasan waktu, tenaga, dan dana (Arikunto 2010, h.183).

\section{Metode Angket (Kuesioner)}

Kuesioner merupakan suatu teknik pengumpulan data yang dilakukan atau dilaksanakan dengan cara memberikan seperangkat pertanyaan atau pernyataan tertulis kepada responden untuk dijawab. Kuesioner merupakan teknik 
pengumpulan data yang dilakukan secara efisien bila peneliti tahu dengan pasti variabel yang akan di ukur dan tahu apa yang diharapkan responden. Selain itu, kuesioner juga cocok digunakan dengan jumlah responden cukup besar dan tersebar di wilayah yang luas. Kuesioner juga dapat berupa pertanyaan-pertanyaan tertutup atau terbuka, dan dapat diberikan kepada responden secara langsung ataupun dikirim melalui pos atau internet.

\section{Teknik Analisis Data}

Teknis analisis data ini merupakan salah satu cara yang digunakan peneliti untuk mengetahui sejauh mana variabel yang mempengaruhi variabel yang lain agar data yang dikumpulkan tersebut dapat bermanfaat maka dari itu harus diolah atau dianalisis terlebih dahulu sehingga dapat dijadikan dalam mengambil keputusan.

Analisis data yang digunakan dalam penelitian adalah sebagai berikut:

\section{Analisis Kualitatif}

Analisis kualitatif merupakan suatu analisis data yang tidak dapat didominasikan dengan menggunakan angka - angka, melainkan disajikan berupa keterangan, penjelasan dan pembahasan teori. Metode kualitatif dengan menggunakan daftar pertanyaan dengan penilaian skala pengukuran nominal seperti :

a. Untuk nilai A, yaitu Sangat Setuju/baik diberi skor : 5 .

b. Untuk nilai B, yaitu Setuju/baik diberi skor : 4.

c. Untuk nilai $\mathrm{C}$, yaitu Netral diberi skor : 3 .

d. Untuk nilai D, yaitu Tidak Setuju/baik diberi skor : 2 .

\section{Analisis Kuantitatif}

Yaitu suatu analisis yang data dalam bentuk angka - angka yang pembahasannya, menghitung dengan statistik yang berdasarkan dari suatu jawaban kuesioner dan responden. Jumlah perhitungan nilai ini lalu dijadikan nilai statistik yang dilakukan dengan menggunakan bantuan program SPSS 20, 
program inilah yang akan dijadikan bukti dari pengaruh dan hubungan antara variabel - variabel penelitian. 


\section{Analisis Regresi Linear Berganda}

Dalam penelitian ini digunakan metode kuantitatif. Analisis ini yang sering kita Rumus persamaan regresi linear berganda yaitu :

$$
Y=a+b_{1} X_{1}+b_{2} X_{2} \quad\{\text { Sugiyono 2012, h. 192\} }
$$

Ket:

$$
\begin{aligned}
& \mathrm{Y}=\text { Kinerja pegawai. } \\
& \mathrm{X}_{1}=\text { Pengawasan } \\
& \mathrm{X}_{2}=\text { Komunikasi. } \\
& \mathbf{A}=\text { Konstanta } \\
& \mathrm{b}_{1}, \mathrm{~b}_{2}=\text { Koefisien Regresi. }
\end{aligned}
$$

Di uji pada tingkat signifikan $\boldsymbol{a}($ alpha) 0,05.

\section{Uji Validitas dan Uji Reliabilitas}

Sebelum melakukan uji statistik ini, peneliti terlebih dahulu melakukan item pernyataan yang akan diuji dengan menggunakan uji validitas dan reliabilitas data. Variabel bebas merupakan suatu data yang dijadikan nilai uji yaitu komunikasi dan pengawasan kinerja pegawaiserta variabel terikat. Uji validitas dan uji reliabilitas ini akan diuji diluar sampel atau populasi yaitu 20 responden pegawai kantor Dinas Pemuda dan Olah Raga Kota Lubuklinggau, yang beralamat di Jl. Sriwijaya, Kompleks Sport Center, Kelurahan Petanang Ulu, Kecamatan Lubuklinggau Utara 1 (satu ), Kota Lubuklinggau. Dari hasil uji awal diketahui bahwa alat instrumen (kuesioner) dalam Penelitian ini valid (terlampir).

\section{a. Uji Validitas}

Uji validitas ini akan diuji diluar sampel atau populasi yaitu sebesar 20 responden pegawai kantor Dinas Pemuda dan Olah Raga Kota Lubuklinggau, yang beralamat di Jl. Sriwijaya, Kompleks Sport Center, Kelurahan Petanang Ulu, Kecamatan Lubuklinggau Utara 1 (satu), Kota Lubuklinggau. Dari hasil uji awal diketahui bahwa alat instrumen (kuesioner) dalam Penelitian ini valid (terlampir). Uji Validitas ini digunakan untuk meneliti sejauh mana indikatorindikator yang akan membentuk suatu konsep yang dapat mewakili bentuk atau variabel di dalam suatu penelitian. Suatu konsep akan mewakili variabel yang 
dapat dibentuk sebuah nilai corrected item total correlation (skor korelasi) $>\mathrm{r}$ $(0,444)$ dan alpha 5\%. Jumlah dari pengolahan data mendapatkan hasil bawasannya sebuah indikator dalam bentuk variabel menunjukkan bahwa adanya data yang dapat dikatakan valid atau benar. Berikut data yang menujukkan hasil dari uji validitasnya sebagai berikut:

Tabel 4.37

Hasil uji validitas

\begin{tabular}{|c|c|c|c|c|}
\hline No & Kode Variabel & $\begin{array}{c}\text { Corrected Item-Total } \\
\text { Correlation }\end{array}$ & r Tabel & Validitas \\
\hline \multirow[t]{11}{*}{1.} & \multicolumn{4}{|l|}{ Pengawasan $\left(\mathrm{X}_{1}\right)$} \\
\hline & $\mathrm{P} 1$ & 0.643 & 0.444 & Valid \\
\hline & $\mathrm{P} 2$ & 0.578 & 0.444 & Valid \\
\hline & $\mathrm{P} 3$ & 0.726 & 0.444 & Valid \\
\hline & $\mathrm{P} 4$ & 0.668 & 0.444 & Valid \\
\hline & $\mathrm{P} 5$ & 0.712 & 0.444 & Valid \\
\hline & $\mathrm{P} 6$ & 0.619 & 0.444 & Valid \\
\hline & $\mathrm{P} 7$ & 0.605 & 0.444 & Valid \\
\hline & P8 & 0.599 & 0.444 & Valid \\
\hline & P9 & 0.865 & 0.444 & Valid \\
\hline & $\mathrm{P} 10$ & 0.728 & 0.444 & Valid \\
\hline \multirow[t]{11}{*}{2.} & \multicolumn{4}{|l|}{ Komunikasi $\left(\mathrm{X}_{2}\right)$} \\
\hline & K1 & 0.547 & 0.444 & Valid \\
\hline & K2 & 0.507 & 0.444 & Valid \\
\hline & K3 & 0.662 & 0.444 & Valid \\
\hline & K4 & 0.615 & 0.444 & Valid \\
\hline & K5 & 0.582 & 0.444 & Valid \\
\hline & K6 & 0.554 & 0.444 & Valid \\
\hline & K7 & 0.671 & 0.444 & Valid \\
\hline & K8 & 0.556 & 0.444 & Valid \\
\hline & K9 & 0.734 & 0.444 & Valid \\
\hline & K10 & 0.576 & 0.444 & Valid \\
\hline \multirow[t]{11}{*}{3} & \multicolumn{4}{|l|}{ Kinerja $(\mathrm{Y})$} \\
\hline & $\mathrm{KP} 1$ & 0.639 & 0.444 & Valid \\
\hline & KP2 & 0.563 & 0.444 & Valid \\
\hline & KP3 & 0.749 & 0.444 & Valid \\
\hline & KP4 & 0.824 & 0.444 & Valid \\
\hline & KP5 & 0.550 & 0.444 & Valid \\
\hline & KP6 & 0.698 & 0.444 & Valid \\
\hline & KP7 & 0.746 & 0.444 & Valid \\
\hline & KP8 & 0.735 & 0.444 & Valid \\
\hline & KP9 & 0.628 & 0.444 & Valid \\
\hline & KP10 & 0.744 & 0.444 & Valid \\
\hline
\end{tabular}

Sumber: Pengolahan Data SPSS, Tahun 2013 


\section{b. Uji Reliabilitas}

Dalam penelitian, reliabilitas merupakan sejauh mana pengukuran dari suatu tes tetap konsisten setelah dilakukan berulang-ulang terhadap subjek dan dalam kondisi yang sama. Penelitian dianggap dapat diandalkan apabila memberikan hasil yang konsisten untuk pengukuran yang sama. Berikut tabel olahan datanya sebagai berikut:

Tabel 4.38

Hasil uji reliabilitas

\begin{tabular}{|c|l|c|c|c|}
\hline No & Kode Variabel & Hasil Pengukuran $(\boldsymbol{\alpha})$ & $\mathbf{r}$ tabel & Reliabilitas \\
\hline 1. & Pengawasan $\left(\mathrm{x}_{1}\right)$ & 0.902 & 0.444 & Reliabel \\
\hline 2. & Komunikasi $\left(\mathrm{X}_{2}\right)$ & 0.871 & 0.444 & Reliabel \\
\hline 3 & Kinerja pegawai & 0.907 & 0.444 & Reliabel \\
\hline
\end{tabular}

Sumber: Pengolahan Data SPSS, Tahun 2013

\section{Uji Asumsi Klasik}

Merupakan persyaratan statistik yang harus dipenuhi pada analisis regresi linier berganda yang bebbasis ordinary least square (OLS). Regresi linear OLS adalah sebuah model regresi linear dengan metode perhitungan kuadrat terkecil atau yang di dalam bahasa inggris desebut dengan istilah ordinary least square. Di dalam model regresi ini, ada beberapa syarat yang harus dipenuhi agar model peramalan yang dibuat menjadi valid sebagai alat peramalan. Syarat-syarat tersebut apabila dipenuhi semuanya, maka model regresi linear tersebut dikatakan BLUE. Blue adalah singkatan dari Best linear Unbiased Esrimation. Data bisa dilihat di bawah ini pengawasan ( $\mathrm{X}_{1}$ ) dengan uji asumsi klasik, Komunikasi ( $\mathrm{X}_{2}$ ) dan kinerja pegawai ( $\mathrm{Y}$ ) dengan menggunakan SPSS 20. 


\section{a. Uji Normalitas.}

Merupakan sebuah uji yang dilakukan dengan tujuan untuk menilai sebaran data pada sebuah kelompok data atau variabel, apakah sebaran data tersebut berdistribusi normal ataukah tidak. Pertanyaan apa itu uji normalitas atau apa yang dimaksud dengan normal kami dapatkan beberpa bulan yang lalu dari salah seorang user channel youtube kami, terlihat disitu pertanyaan tentang pengertian uji normalitas dan apa fungsinya. Selain itu berdasarkan pengalaman kami selaku analyze olah data spss, sering terjadi kendala dalam hal ini, yaitu data penelitian yang didapatkan tidak normal, maka dari itu kami mencoba menggambarkan definisi ataupun pemahaman kami tentang normalitas data.

Secara definisi uji normalitas akan kami jelaskan sebagai berikut :

Uji normalitas bertujuan untuk mengetahui apakah data yang kita miliki berdistribusi normal atau mendekati normal, yaitu data berdistribusi bentuk lonceng (bell shaped) atau data tersebut tidak menceng ke kiri tau menceng ke kanan (santoso 2010,43).

Saeful dan Bahruddin (2014, 113) menyatakan bahwa uji normalitas dilakukan untuk mengetahui normal atrau tidaknya suatu distribusi data yang nantinya hal ini menjadi penting diketajui karena berkaitan dengan pemilihan uji statistik yang tepat untuk digunakan. Berdasarkan dua penjelasan di atas, dapt dijelaskan bahwa yang menjadi intinya adalah distribusi atau sebaran data. Data yang normal adalah data yang menyebar merata dan polanya tidak menceng kekiriataupun kekanan. Untuk mengetahui sebaran datanya silahkan download data yang tidak normal dan data yang normal kemudian bandingkan. Makan akan terlihat jelas perbedaannya bahwa jika data tidak normal maka polanya akan terlihat menceng dan distribusinya juga tidak merata. Uji normalitas dapat dilakukan dengan berbagai cara, diantaranya lilliefors, p-plot, kolmogorov, chi square dan lain-lain.

Data yang di analisis dengan menggunakan metode SPAA bisa di lihat dari hasil output (keluar) data primer bisa dilihat pada gambar Histogram juga 
normal P-P Plaot of Regression Standardized Residual. Data tersebut dapat di lihat pada gambar 4.2 dan 4.3 berikut:

Uji normalitas sebaran yaitu sebuah uji yang dilakukan dengan tujuan untuk menilai sabaran data pada sebuah kelompok data atau variabel, apakah sebaran data tersebut berdistribusi normal ataukah tidak. Distribusi normal bisa di lihat dari output histogram yang bersifat normal. Uji normalitas berguna untuk menentukan data yang telah dikumpulkan berdistribusi normal atau diambil dari populasi normal. Lihat gambar 4.2, Histogram Uji Normalitas terlihat bahwa setiap data meluas atau menyebar ke semua daerah yang Normal. Daerah Normal itu sendiri yaitu daerah yang terletak di bawah kurva tersebut yang rupanya seperti lonceng terbalik atau miring.

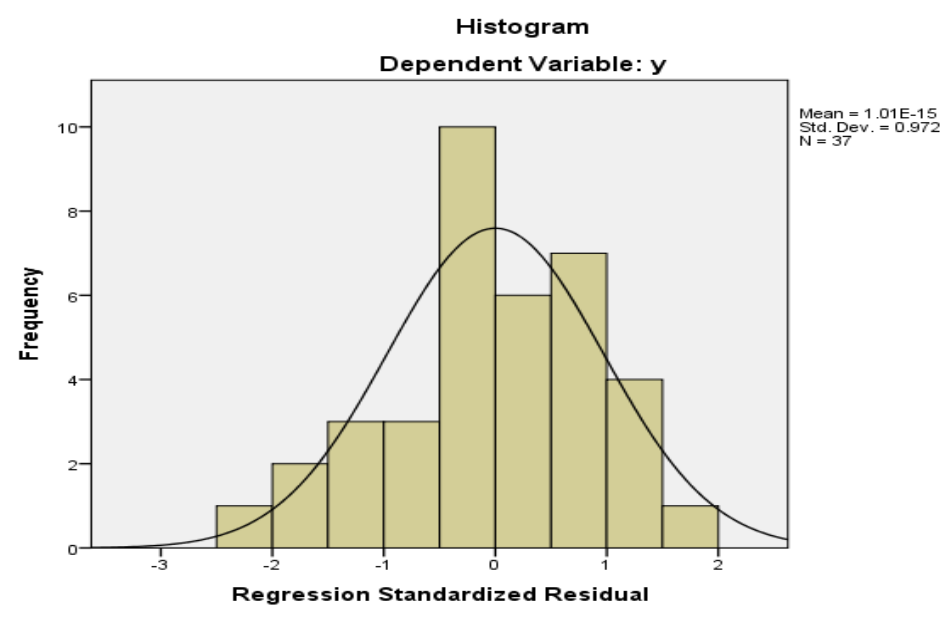

Sumber: Pengolahan Data SPSS, Tahun 2013

Gambar 4.2.

\section{Histogram Uji Normalitas}

Output gambar 4.3 bisa menjadi bukti data berdistribusi normal pada hasil P-P Plot. Titik-titik menyebar sepanjang garis regresi. Hal tersebut mengartikan sebaran data nya merata sehingga dapat dihasilkan Y yang merata pula pada garis Regresi. 


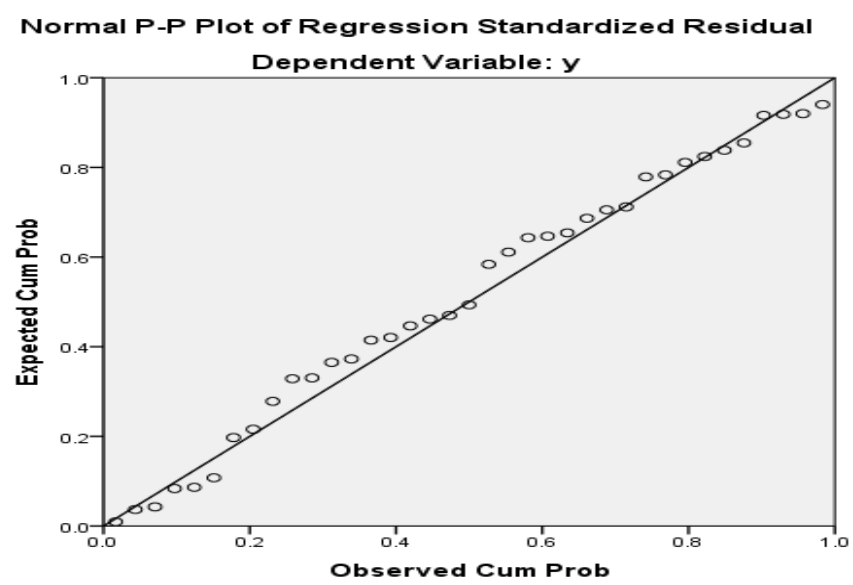

Sumber: Pengolahan Data SPSS, Tahun 2013

Gambar 4.3

\section{Hasil P-P Plot Uji Normalitas}

Dari analisis kurva dapat dilihat bahwa data menyebar disekitar diagram dan mengikuti model regresi sehingga dapat disimpulkan bahwa data yang diolah merupakan data yang berdistribusi normal sehingga uji normalitas terpenuhi.

Uji Kolmogorov Smirnov (KS) merupakan alat uji statistik yang digunakan untuk menentukan apakah suatu sampel berasal dari suatu populasi yang memiliki sebaran data tertentu atau mengikuti distribusi statistik tertentu. Data uji Kolmogorov Smirnov dikatakan normal jika nilai signifikansi sebesar $(>0,05)$.

Tabel 4.39

Hasil Uji Normalitas

Uji Kolmogorov-Smirnov satu sampel

\begin{tabular}{|ll|r|r|r|}
\hline & & \multicolumn{1}{|c|}{$\mathrm{x} 1$} & \multicolumn{1}{c|}{$\mathrm{x}$} & $\mathrm{y}$ \\
\hline $\mathrm{N}$ & & 37 & 37 & 37 \\
Parameter normal ${ }^{\mathrm{a}, \mathrm{b}}$ & Artinya & 3.8216 & 3.7568 & 3.4892 \\
& Std. Deviasi & .57161 & .45676 & .66866 \\
Paling Ekstrim & mutlak & .173 & .135 & .165 \\
Perbedaan & Positif & .173 & .118 & .125 \\
Kolmogorov Smirnov & Negatif & -.124 & -.135 & -.165 \\
Asymp. Sig. (2-tailed) & & 1.050 & .823 & 1.006 \\
& & $\mathbf{. 2 2 0}$ & $\mathbf{. 5 0 8}$ & $\mathbf{. 2 6 3}$ \\
\hline
\end{tabular}

a. Uji Distribusi Normal. 
b. Dihitung dari data.

Sumber : Pengolahan Data dengan menggunakan SPSS, Tahun 2013

Cara menganalisis data ini, kita bisa melihatlihat dengan baris "Asymp. Sig. (2-tailed)" baris bagian bawah. jika nilai signifikan di setiap variabel akan lebih dari ( >0,05 ) maka uji normalitas bisa tercukupi. dilihat dari hasil uji normalitas menampakkan bahwa nilai signifikansi ( >0,05 ), kita dapat menyimpulkan dengan kata normal. Pada tabel 4.39 nilai signifikan "Asymp. Sig. ( 2-tailed )" lebih dari ( $>0,05)$. Kita bisa menyebutnya bahwa uji normalitasnya tersebut terpenuhi.

\section{b.Uji Multikolinieritas}

Uji multikolinieritas adalah uji yang dilakukan untuk memastikan apakah di dalam sebuah model regresi ada interkolerasi atau kolinearitas antar variabel bebas. Hasil yang baik dari model regresi hendaknya tidak akan terjadi korelasi di antara variabel independennya. Andai variabel independennya saling berkorelasi atau berhubungan, maka variabel-variabel ini tidak orthogonal,Imam Ghozali (dalam artikel Sisca 2007, h. 91). Untuk mengetahui munculnya multikolinearitas, dapat dijelaskan dari Value Inflation Factor ( VIF ). jika nilai VIF ( > 10 ) terjadi multikolinieritas. Sebaliknya, jika VIF ( < 10 ), tidak terjadi multikolinearitas, Wijaya (dalam artikel Siska 2009, h.119).

Analisis data SPSS dapat kita lihat dari hasil output data primer pada tabel 4.40 "Coefficients", sebagai berikut :

Tabel 4.40

Coefficients $^{\mathrm{a}}$

\begin{tabular}{|c|c|c|c|c|c|c|c|}
\hline \multirow[t]{2}{*}{ Model } & \multicolumn{2}{|c|}{$\begin{array}{l}\text { Unstandardized } \\
\text { Coefficients }\end{array}$} & \multirow{2}{*}{\begin{tabular}{|c}
$\begin{array}{c}\text { Standardi } \\
\text { zed } \\
\text { Coefficie } \\
\text { nts }\end{array}$ \\
Beta
\end{tabular}} & \multirow[t]{2}{*}{$\mathrm{T}$} & \multirow[t]{2}{*}{ Sig. } & \multicolumn{2}{|c|}{$\begin{array}{c}\text { Collinearity } \\
\text { Statistics }\end{array}$} \\
\hline & B & $\begin{array}{l}\text { Std. } \\
\text { Error }\end{array}$ & & & & Tolerance & VIF \\
\hline (Constant) & $-1,214$ & .421 & & -2.883 & .007 & & \\
\hline $\mathrm{X} 1$ & 561 & .148 & .480 & 3.789 & .001 & .361 & 2.771 \\
\hline $\mathrm{X} 2$ & 681 & .185 & .465 & 3.677 & .041 & .361 & 2.771 \\
\hline
\end{tabular}


a. Dependent Variable: Y

Sumber: Pengolahan Data SPSS, Tahun 2013

Data yang keluar atau output pada tabel 4.40 di atas, Uji Multikolinearitas didapati untuk masing-masing dari nilai VIF prediktor. Untuk menjadi sebuah persyaratan dapat dibilang terbebas dari multikolinearitas yaitu apabila nilai VIF prediktor tidak kurang dari nilai 10 nilai VIF 2,771. Penelitian yang dilakukan dapat kita diketahui bahwa nilai dari semua nilai VIF ( $<10$ ) atau nilai hanya berkisar antara $1-10$, ini berarti tidak terjadinya multikolonieritas. Jadi dapat dikatakan bahwa uji multikolonieritas tercukupi atau terpenuhi.

\section{c. Uji Heteroskedastisitas}

Uji heteroskedastisitas ini bertujuan untuk menguji apakah dalam model regresi linear terjadi ketidaksamaan varians dari residual satu pengamatan ke pengamatan yang lain. Keadaan dari uji heteroskedastisitas ini menyatakan bahwa adanya ketidaksamaan varians dari residual suatu penelitian atau ke pengamatan yang tidak sama. Untuk menguji ada tidaknya uji heterokedastisitas kita mengunakan suatu metode yang akan mengakibatkan penapsiran koefisien-koefisien nilai regresi menjadi tidak efisien. Semestinya hasil dari penapsiran ini akan bisa dikatakan belum cukup atau kurang, salah satu dasar regresi linier akan bertentangan dengan uji heterokedastisitas yaitu bahwasanya nilain pengamatannya harus sama antara varians dan residualnya bisa disebut juga dengan uji heterokedastitas, Elmasari (dalam artikel Sisca 2010, h. 53). Nilai residual variabel dependen bisa disebut juga dengan Uji Heteroskedastisitas atau Homogenitas menggunakan Scatter Plot. Berikut kita lihat dasar analisisnya yaitu:

a. Seperti titik-titik yang ada akan membentuk pola tertentu yang teratur (bergelombang, melebar kemudian menyempit), maka mengindikasikan telah terjadi heteroskedastisitas, jika ada pola tertentu.

b. Serta titik-titik menyebar di atas dan di bawah angka 0 pada sumbu Y, maka tidak terjadi heteroskedastisitas, jika ada pola yang jelas. 
Jika kita perlu mengamati datanya kita lihat pada gambar 4.4 "Scatterplot" pada hasil keluar atau output data primer,seperti yang kita lihat di bawah ini:

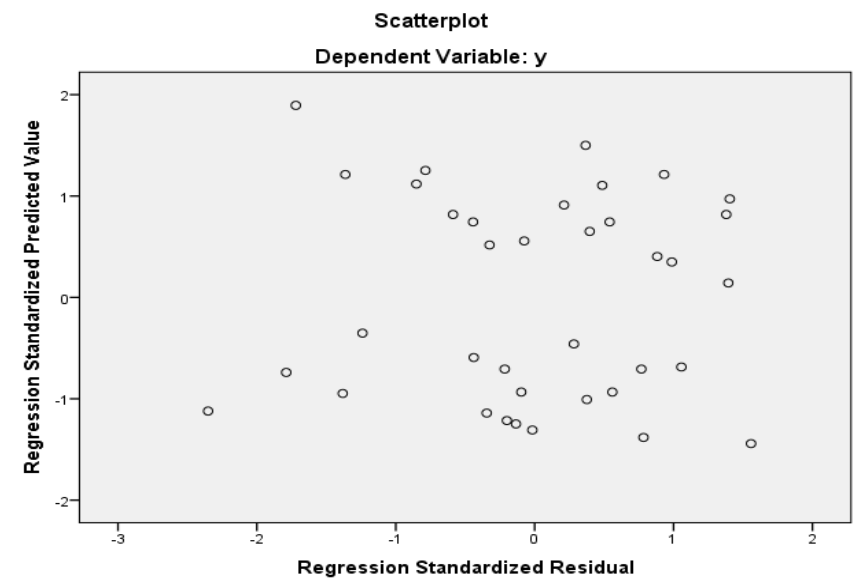

Sumber: Pengolahan Data SPSS, Tahun 2013

\section{Gambar 4.4}

\section{Hasil Scatterplot Uji Heteroskedastisitas}

Gambar di atas kita ketahui bawasannya uji heteroskedastitas tidak terjadi. karena serta titik-titik menyebar di atas dan bawah atau data menyebar ke segala bidang tidak ada pola yang begitu jelas, sehingga bisa dibilang atau digambarkan bahwa uji heteroskedastisitas terpenuhi atau terpercaya.

\section{d. Uji Autokorelasi}

Uji autokorelasi merupakan pengujian asumsi dalam regresi dimana variabel dependen tidak berkorelasi dengan dirinya sendiri. Maksud korelasi dengan diri sendiri adalah bahwa nilai dari variabel dependen tidak berhubungan dengan nilai variabel itu sendiri, baik nilai variabel sebelumnya atau nilai periode sesudahnya, Santosa dan Ashari (dalam artike Sisca 2005, h. 240).

Dasar pengambilan keputusannya adalah sebagai berikut:

1) Angka D-W di bawah -2 berarti ada autokorelasi positif.

2) Angka D-W diantara -2 sampai +2 berarti tidak ada autokorelasi.

3) Angka D-W di atas +2 berarti ada autokorelasi negative.

Untuk menganalisisnya menggunakan hasil data output SPSS dilihat pada tabel 4.41 "Model Summary", seperti berikut ini: 
Tabel 4.41

Model Summary ${ }^{b}$

\begin{tabular}{|c|c|c|c|c|c|c|c|c|c|c|}
\hline \multirow[t]{2}{*}{ Model } & \multirow[t]{2}{*}{$\mathrm{R}$} & \multirow{2}{*}{$\begin{array}{c}\mathrm{R} \\
\text { Squar } \\
\mathrm{e}\end{array}$} & \multirow{2}{*}{$\begin{array}{l}\text { Adjuste } \\
\text { d R } \\
\text { Square }\end{array}$} & \multirow{2}{*}{$\begin{array}{l}\text { Std. } \\
\text { Error of } \\
\text { the } \\
\text { Estimat } \\
\text { e }\end{array}$} & \multicolumn{5}{|c|}{ Change Statistics } & \multirow{2}{*}{$\begin{array}{l}\text { Durbin- } \\
\text { Watson }\end{array}$} \\
\hline & & & & & $\begin{array}{c}c \mathrm{R} \\
\text { Square } \\
\text { Change }\end{array}$ & $\begin{array}{c}\mathrm{F} \\
\text { Chang } \\
\mathrm{e}\end{array}$ & $\begin{array}{c}\mathrm{df} \\
1\end{array}$ & $\begin{array}{c}\mathrm{df} \\
2\end{array}$ & $\begin{array}{c}\text { Sig. F } \\
\text { Chang } \\
\mathrm{e}\end{array}$ & \\
\hline 1 & .896 & .803 & .792 & .30502 & .803 & $\begin{array}{r}69.50 \\
4\end{array}$ & 2 & 34 & ,000 & 1.894 \\
\hline
\end{tabular}

a. Predictors: (Constant), X2, X1

b. Dependent Variable: Y

Sumber: Pengolahan Data SPSS, Tahun 2013

Dari tabel 4.41 diatas didapatkan nilai Durbin-Watson (DW hitung) sebesar 1,894 atau berdasarkan kriteria yang telah ditentukan DW hitung berada diantara 2 sampai 2 , yakni $-2 \leq 1,894 \leq 2$, maka ini berarti tidak terjadi autokorelasi. Sehingga kesimpulannya adalah Uji Autokorelasi terpenuhi.

\section{e. Uji Linearitas}

Menurut Suliyanto (2012, h. 145), pengujian linieritas dilakukan untuk mengetahui apakah model yang dibuktikan merupakan model linier atau tidak.

Untuk menganalisisnya menggunakan hasil data output SPSS dilihat pada tabel 4.42 dan 4.43 "ANOVA Table", sepertiberikut ini: 
Tabel 4.42

Hasil Uji Linearitas antara Pengawasan dan Kinerja Pegawai ANOVA Table

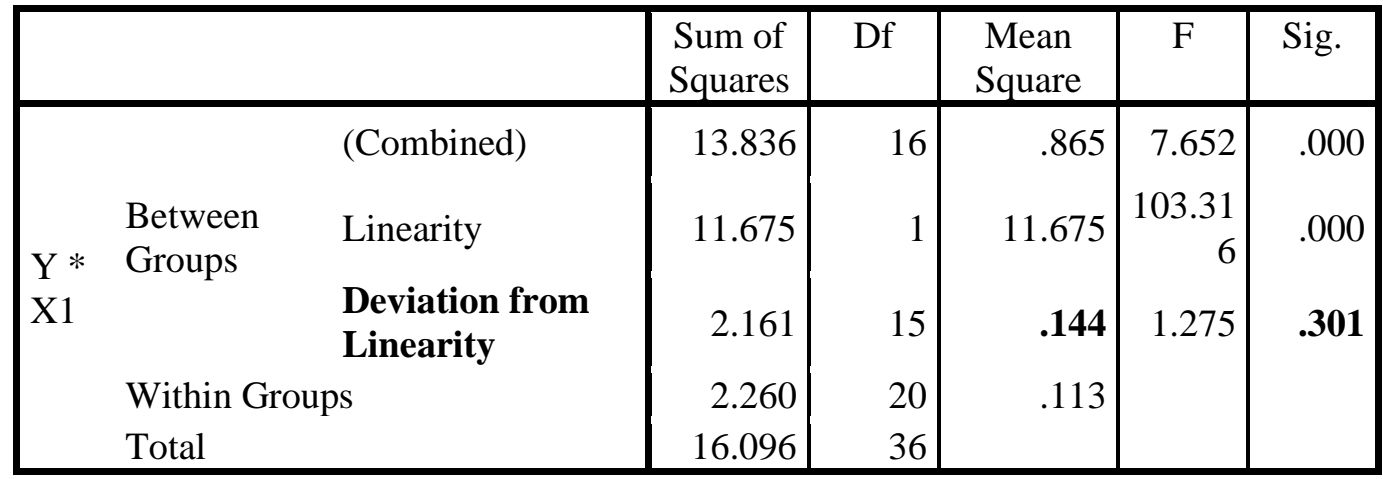

Sumber: Pengolahan Data SPSS, Tahun 2013

Tabel 4.43

Hasil Uji Linearitas antara Komunikasi dan Kinerja Pegawai ANOVA Table

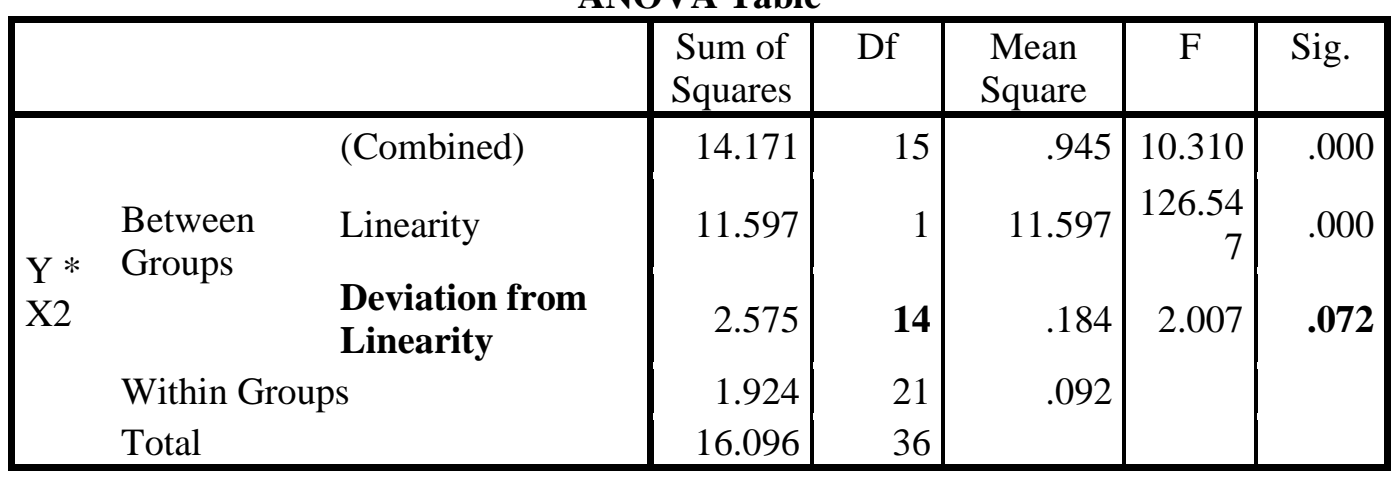

Sumber: Pengolahan Data SPSS, Tahun 2013

Hasil Uji Linearitas di atas (tabel 4.42 dan Tttabel 4.43) membuktikan bahwa hubungan yang terjadi antara variabel bebasnya dengan variabel terikatnya bersifat linear. Pada tabel 4.42, yang menggambarkan uji hubungan bersifat linear antara Kinerja Pegawai dan Pengawasan nilai Sig. pada Deviation of Linearity sebesar 0,301. Sedangkan pada tabel 4.43, yang menggambarkan uji hubungan bersifat linear antara Kinerja Pegawai dan Komunikasi, nilai Sig. pada Deviation of Linearity sebesar 0.72 .

Kedua nilai Sig. pada uji linearitas baik antar Kinerja Pegawai dengan Pengawasan, maupun Kinerja Pegawai dengan Komunikasi sama-sama (>0.05). Apabila nilai Sig. lebih besar dari (0.05) mengartikan hubungan prediktor dan dependen variabel bersifat linear, maka kedua nilai Sig. pada ANOVA Table, memenuhi syarat linear. 
Kesimpulan Uji Linearitas di sini berarti bahwa antar variabel bebas dan terikat yang diteliti bukanlah sesuatu yang memiliki suatu sifat siklus dan tidak linear. Siklus sendiri biasanya terjadi pada hal-hal yang tertentu.

Berdasarkan hasil pengujian reliabilitas, validitas dan asumsi klasik di atas menunjukkan bahwa dapat disimpulkan tidak terjadi adanya pelanggaran asumsi dan semua data memenuhi syarat untuk diuji selanjutnya, yaitu uji regresi linear bergandadan tidak akan mendapatkan hasil yang bias.

\section{Uji Regresi Linier Berganda}

Uji regresi linier berganda digunakan untuk mengetahui pengaruh data primer yang diuji, yang berasal dari 2 variabel bebas yaitu pengawasan dan komunikasiterhadap kinerja pegawaipada Kantor Unit Pelaksana Teknis Irigasi Musi Rawas Dinas Pekerjaan Umum Pengairan Kabupaten Musi Rawas. Dalam uji ini akan digunakan alat bantu komputer untuk software statistik dengan program SPSS versi 20.0. Hasil uji secara rinci akan disajikan pada tabel di bawah ini:

Tabel 4.44

\section{Hasil regresi linier berganda}

\begin{tabular}{|c|c|c|c|}
\hline & $\beta$ & $\mathrm{t}_{\text {hitung }}$ & Sig \\
\hline$\beta_{0}$ & -1.214 & -2.883 & 0.007 \\
\hline $\mathrm{X}_{1}$ & 0.561 & 3.789 & 0.001 \\
\hline $\mathrm{X}_{2}$ & 0.681 & 3.677 & 0.001 \\
\hline $\mathrm{R}=0.896$ & $\mathrm{R}^{2}=0.803$ & $\mathrm{~F}_{\text {hitung }}=69.504$ & $\mathrm{Sig} \mathrm{F}=0.000$ \\
\hline
\end{tabular}

Sumber: Pengolahan Data SPSS, Tahun 2013

Dari hasil rekapitulasi hasi regresi linier berganda di atas adapun persamaan regresi untuk mengestimasi variabel terikat dengan menggunakan seluruh variabel bebas adalah sebagai berikut :

$$
Y=-1.214+0,561 X_{1}+0,681 X_{2}
$$

Keterangan :

$\begin{array}{ll}\mathrm{Y} & =\text { Kinerja pegawai } \\ \mathrm{X}_{1} & =\text { Pengawasan } \\ \mathrm{X}_{2} & =\text { Komunikasi }\end{array}$




$$
\begin{array}{ll}
\beta_{0} & =\text { Konstanta } \\
\beta & =\text { Koefisien Regresi } \\
\mathrm{R} & =\text { Koefisien korelasi } \\
\mathrm{R}^{2} & =\text { Koefisien determinasi } \\
\mathrm{t}_{\text {hitung }} & =\text { Hasil uji parsial } \\
\mathrm{F}_{\text {hitung }} & =\text { Hasil uji Serentak } \\
\text { sig } & =\text { Signifikansi }
\end{array}
$$

Dari persamaan nilai estimasi fungsi regresi di atas terlihat bahwa nilai konstanta yang diperoleh adalah sebesar -1.214. Hal ini menggambarkan bahwa tanpa dipengaruhi oleh variabel bebas (X) maka kinerja pegawai(Y) adalah sebesar -1.214 atau $-12.14 \%$, dan terdapat pengaruh yang negatif antara variabel bebas dan variabel terikat, (dalam jurnal Endang Dwiningsih 2011).

Nilai koefisien regresi mewakili variabel pengawasan yang diperoleh sebesar 0,561 menunjukkan bahwa setiap perubahan pada pengawasanmaka kinerja pegawai akan berubah berbanding lurus, yakni sebesar 0,561 dengan asumsi variabel bebas lainnya konstan.

Nilai koefisien regresi mewakili variabel komunikasi yang diperoleh sebesar 0,681 menunjukkan bahwa setiap perubahan pada komunikasi maka kinerja pegawai akan berubah berbanding lurus, yakni sebesar 0,681 dengan asumsi variabel bebas lainnya yaitu pengawasan konstan.

Nilai koefisien korelasi (R) yang diperoleh, adalah positif sebesar 0,896. Hal ini dapat diartikan bahwa hubungan antara variabel bebas terhadap variabel terikat secara bersama-sama dapat dikatakan sangat tinggi yaitu sebesar 89,6\%. Sedangkan suatu korelasi dapat dikatakan sempurna jika nilai yang diperoleh mencapai 1 dengan asumsi bahwa variabel bebas lainnya konstan.

Nilai koefisien determinan $\left(\mathrm{R}^{2}\right)$ yang diperoleh, adalah sebesar 0,803 , dapat diartikan bahwa variasi perubahan nilai variabel terikat (kinerja) dapat dijelaskan oleh seluruh variabel bebas (pengawasan dan komunikasi) secara bersama-sama (simultan) sebesar 80,3\% dan sisanya sebesar 19,7\% dijelaskan oleh variabel lain. 


\section{Uji Serentak (Uji F)}

Uji serentak (uji F) dilakukan untuk melihat pengaruh dari variabel bebas terhadap variabel terikat secara bersama. Berdasarkan rekapitulasi hasil uji regresi linier berganda, didapat bahwa nilai $\mathrm{F}$ hitung yang diperoleh adalah 69,504> F tabel $=3$,26dan tingkat kemaknaan secara serentak $\operatorname{sig} \mathrm{F}$ adalah 0,000. Hal ini menunjukkan bahwa secara bersama-sama (simultan) variabel bebas penelitian (pengawasan dan komunikasi) memiliki pengaruh yang signifikan terhadap variabel terikat (kinerja).

Hasil uji serentak (Uji F) ini juga membuktikan bahwa hipotesis pertama penelitian ini yang berbunyi "Diduga variabel pengawasan, dan komunikasipegawai secara bersama-sama memiliki pengaruh yang signifikan terhadap kinerja pegawaiKantor Unit Pelaksana Teknis Irigasi Musi Rawas Dinas Pekerjaan Umum Pengairan Kabupaten Musi Rawas" terbukti kebenarannya dan hipotesis diterima.

\section{Pembahasan}

Hasil penelitian menunjukkan bahwa pengawasan dan Komunikasi berpengaruh terhadap kinerja pegawai. Hal ini dapat dilihat dari persamaan hasil regresi sebagai berikut: $\mathrm{Y}=-1,214+0,561 \mathrm{X}_{1}+0,681 \mathrm{X}_{2}$. Artinya Pengawasan yang baik seharusnya diterapkan, dilakukan oleh pegawai agar dapat meningkatkan kinerja pegawai, serta menjaga nama baik instansi tersebut. Sedangkan Komunikasi yang baik serta lancar akan mempermudah arus informasi. Hal inidapat mengurangi atau menghindari ketidaktahuan pekerjaan, kesalahan kerja, kesalahan komunikasi dan sebagainya, sehingga kinerja pegawaidapat meningkat.

Pengujian hipotesis dengan uji $F$ memperoleh nilai $F_{\text {hitung }}>F_{\text {tabel }}(69,504>3,26)$ pada taraf signifikansi 5\%, maka pengawasan dan Komunikasi secara bersamasama berpengaruh signifikan terhadap kinerja pegawaiKantor Unit Pelaksana Teknis Irigasi Musi Rawas Dinas Pekerjaan Umum Pengairan Kabupaten Musi Rawas. Hal ini berarti Pengawasan dan Komunikasi merupakan faktor-faktor yang mempengaruhi kinerja pegawai. 
Hasil uji variabel bebas (pengawasan dan Komunikasi) berkorelasi positif tinggi terhadap variabel terikat (kinerja pegawai Kantor Unit Pelaksana Teknis Irigasi Musi Rawas Dinas Pekerjaan Umum Pengairan Kabupaten Musi Rawas, yaitu sebesar $89,6 \%(\mathrm{R}=0,896)$. Selanjutnya, Variasi perubahan variabel terikat (kinerja) dapat djelaskan oleh variabel bebas (pengawasan dan Komunikasi) secara bersama-sama (simultan) sebesar $80,3 \%\left(\mathrm{R}^{2}=0,803\right)$ sedangkan sisanya sebesar 19,7\% dijelaskan oleh variabel lain seperti disiplin kerja, budaya kerja, kepemimpinan danlingkungan kerja. Hal ini dapat diartikan apabila dilakukan perubahan secara bersama-sama maka akan dapat mempengaruhi kinerja pegawai Kantor Unit Pelaksana Teknis Irigasi Musi Rawas Dinas Pekerjaan Umum Pengairan Kabupaten Musi Rawas sebesar 80,3\%.Kesimpulannya Pengaruh Pengawasan terhadap Kinerja Pegawai dilihat dari nilai Beta 0,561 ini menunjukkan bahwa besarnya Pengaruh Pengawasan terhadap Kinerja Pegawai sebesar 56,1 \% dan Pengaruh Komunikasi terhadap Kinerja Pegawai dilihat dari nilai Beta 0,681 ini menunjukkan bahwa besarnya Pengaruh Komunikasi terhadap Kinerja Pegawai sebesar 68,1\%.

Hal ini sesuai dengan penelitianMenurut Endang, (2011) tentang pengaruh komunikasi, Motivasi kerja, lingkungan kerja, kemampuan kerja, manajemen konflik, dan tingkat kesejahteraan terhadap kinerja karyawan pada akademi perawatan panti kosala sukakarta.Penelitian di Akper Panti Kosala Surakarta denganPopulasi terdiri dari 39 responden. Pengambilan data abtained langsung olehkuesioner.Penelitian di Akper Panti Kosala Surakarta menyimpulkanhat: 1) komunikasi, motivasi, kemampuan kerja dan karyawan kita 11 menjadiindividual memiliki efek positif dan signifikan terhadap karyawan, sedangkanlingkungan kerja tidak signifikan tidak berpengaruh dan manajemen konflik tidakberpengaruh signifikan terhadap kinerja pegawai, 2) komunikasi, motivasi, lingkungan kerja, kemampuan kerja, manajemen konflik dan karyawan yang secara simultan berpengaruh positif dan signifikan terhadap dipekerjaan dari kinerja pegawai, persamaan regresi yang dihasilkan adalah akper panti kosala Surakarta: Y = $8.963+0.214 \times 1+0.383 \times 2-0.140 \times 3+0.612 \times 4-0.196 \times 5+0,507 \times 6+e$, the koefisien determinasi adjusted R $2=0,895$.berati bahwa komunikasi, Motivasi, 
lingkungan kerja, kemampuan kerja, konflik manajemen dan karyawan kesejahteraan menentukan variabilitas pada memperkerjakan EES dari kinerja pegawai sekitar $89,5 \%$, tetap $10,5 \%$ ditentukan oleh faktor lain di luar model, 3 ) faktor yang paling dominan di pengaruhi kinerja karyawaan adalah kemampuan kerja yang ditunjukkan oleh regresi koefisien kemampuan kerja 0,612 adalah yang terbesar diantara faktor-faktor lain.

\section{KESIMPULAN DAN SARAN}

\section{Kesimpulan}

Berdasarkan analisis dan pembahasan maka dapat ditarik beberapa kesimpulan sebagai berikut:

a. Hasil analisis regresi memperoleh persamaan: $\mathrm{Y}=-1,214+0,561 \mathrm{X}_{1}+0,681 \mathrm{X}_{2}$ yang artinya kinerja pegawai dipengaruhi oleh Pengawasan dan Komunikasi pegawai. Hasil analisis regresi juga memperoleh nilai koefisien korelasi $(\mathrm{R}=0,896)$ atau sebesar $(89,6 \%)$ dan nilai koefisien determinasi $\left(\mathrm{R}^{2}=0,803\right)$ atau sebesar $(80,3 \%)$. Ini berarti $(80,3 \%)$ variabel kinerja pegawai dipengaruhi oleh variabel Pengawasan dan Komunikasi . Sisanya sebesar (19,7\%) dijelaskan oleh variabel lain, seperti, disiplin kerja, budaya kerja, kepemimpinan dan lingkungan kerja.Kesimpulannya Pengaruh Pengawasan terhadap Kinerja Pegawai dilihat dari nilai Beta 0,561 ini menunjukkan bahwa besarnya Pengaruh Pengawasan terhadap Kinerja Pegawai sebesar 56,1 \% dan Pengaruh Komunikasi terhadap Kinerja Pegawai dilihat dari nilai Beta 0,681 ini menunjukkan bahwa besarnya Pengaruh Komunikasi terhadap Kinerja Pegawai sebesar $68,1 \%$.

b. Pengawasan dan Komunikasi secara bersama-sama mempunyai pengaruh yang signifikan terhadap kinerja pegawai Kantor Unit Pelaksana Teknis Irigasi Musi Rawas Dinas Pekerjaan Umum Pengairan Kabupaten Musi Rawas. Hal ini dapat terbukti hasil uji F yang memperoleh $F_{\text {hitungsebesar 69,504 diterimapada }}$ taraf signifikansi 0,000\%. Kesimpulannya pengaruh Pengawasan dan 
Komunikasi terhadap kinerja Pegawai dilihat dari nilai $\mathrm{R}^{2} 0,803$ ini menunjukkan bahwa besarnya pengaruh Pengawasan dan Komunukasi terhadap kinerja Pegawai sebesar $80,3 \%$.

\section{Saran}

Berdasarkan kesimpulan yang telah dikemukakan, disampaikan beberapa saran sebagai berikut:

1. Pengawasanperlu dipertahankan serta ditingkatkan agar didapat kebijakankebijakan yang benar-benar memperhatikan kinerja pegawai Kantor Unit Pelaksana Teknis Irigasi Musi Rawas Dinas Pekerjaan Umum Pengairan Kabupaten Musi Rawas.

2. Komunikasi yang berpengaruh dominan terhadap kinerja pegawai Kantor Unit Pelaksana Teknis Irigasi Musi Rawas Dinas Pekerjaan Umum Pengairan Kabupaten Musi Rawas hendaknya lebih ditingkatkan agar kinerja pegawai Kantor Unit Pelaksana Teknis Irigasi Musi Rawas Dinas Pekerjaan Umum Pengairan Kabupaten Musi Rawas dapat dipertahankan dan ditingkatkan dimasa yang akan datang. Salah satu jalan yang dapat ditempuh dalam meningkatkan komunikasi pegawai adalah pada tahap perekrutan ataupun promosi pegawai yang akan menempati salah satu posisi, hendaknya pegawai yang direkrut benar-benar kualifikasinya sesuai dengan syarat dari jabatan atau pegawaian itu sendiri. Pola Pembinaan training bagi pegawai disesuaikan dengan pengembangan komunikasi pribadi maupun pegawaian. Selain hal tersebut perlu juga diperhatikan indikator-indikator yang mendukung persoalan komunikasi itu sendiri, yang meliputi ; pegawai dituntut untuk meningkatkan pengetahuan dan aspek teknis dalam pegawaian, bekerja sesuai dengan prosedur yang telah ditetapkan, memiliki kemampuan memimpin dan hal lainnya yang berkatian dengan komunikasi pegawaian itu sendiri. 


\section{DAFTAR PUSTAKA}

Agung Pramudya. 2013. Pengaruh Gaya Kepemimpinan dan Pengawasan Terhadap Kinerja Karyawan Pada PT. Tiki Cabang Pekanbaru. ( Jurnal Skripsi )

Andrian Sutedi. 2010. Aspek Hukum Pengadaan Barang Dan Jasa Dan Berbagai Permasalahannya. Cetakan ke - 3. Jakarta: Sinar Grafika.

Derafitriabiantara. 29 september 2012. Arti, Indikator, Tahapan, Fungsi, Ciri-ciri dan Permasalahan dari Komunikasi. ( online ), ( http : derafitria. Wordpress.com, di akses 06 mei 2013 ).

Dennyimamazharı. 11 Januarı 2013. Pengawasan dalam Perkantoran ( online ), ( dennymamazhari. Wordpress. Com ).

Edy Sutrisno. 2009. Manajemen Sumber Daya Manusia. Cetakan ke - 1. Jakarta : Kencana Prenada Media Group.

Etta Mamang Sangadji \& Sopiah. 2010. Metodologi Penelitian. Yogyakarta : CV. Andi Offset.

Endang Dwiningsih. 2011. pengaruh komunikasi, Motivasi kerja, lingkungan kerja, kemampuan kerja, manajemen konflik, dan tingkat kesejahteraan terhadap kinerja karyawan pada akademi perawatan panti kosala sukakarta

George R. Terry. 2011. Dasar - dasar Manajemen. Cetakan ke - 12. Jakarta : PT. Bumi Aksara.

Irine Diana Sari Wijayanti. 2012. Manajemen. Cetakan ke - 2 Yogyakarta: Nuha Medika.

Imam Ghozali. 2005. Analisis Multivariate dengan program SPSS. Semarang: Badan Penerbit Universitas Diponogoro.

Klasik. 2011. pengaruh motivasi dan pengawasaan terhadap produktivitas kerja karyawan pada PT. Yudistira Bumi Bhakti Halmahera Timur

Miftah Thoha. 2012. Perilaku Organisasi Konsep Dasar Dan Aplikasinya. Cetakan ke - 22. Jakarta: PT. RajaGrafindo Persada.

Markoni Badri. 2012. Pengaruh Komunikasi, Pengawasan dan Keahlian Terhadap Kinerja Pejabat Komitmen Dalam Proyek APBN Di Sumatera Selatan Pada Balai Besar Pelaksanaan Jalan Nasional III.

Sugiyono. 2012. Metode Penelitian Kuantitatif, Kualitatif dan $R d$ D.Cetakan ke 17. Bandung: CV. Alfabe.

Sukamto Reksohadiprojo. 2010. Dasar - Dasar manajemen. Cetakan ke - 7. Yogyakarta: BPFE.

Suharsimi Arikunto. 2010. Prosedur Penelitian suatu Pendekatan Praktik. Cetakan ke - 14. Jakarta : PT. Rineka Cipta.

Sutrisno. 2007 . Pengaruh Kepemimpinan, Komunikasi, dan Motivasi terhdap kinerja Pegwai. Jurnal Manajemen Sumber Daya Manusia vol. 2 No. 1.

STIE. 2013. Pedoman Penyusunan Proposal dan Skripsi. Lubuklinggau : STIE.

Suliyanto. 2011.Ekonometrika Terapan: Teori dan Aplikasi dengan SPSS. Yogyakarta: CV. Andi Offset.

Sisca. 2012. Cara menghitung Asumsi Klasik. (online). (Email: dinaseptyperiska@gmail.com, di akses 17 juli 2013). 
Sari dan Ucihaitachi. 2012. Pengaruh lingkungan Kerja dan Motivasi Kerja Terhadap Kinerja Pegawai Tata Usaha SMP di Kecamatan Pedurungan Kota Semarang. Category: Artikel Pendidikan. (online), (post: By. Ucihaitachi, 19 april 2012, di akses 10 maret 2013).

Wijaya. 2008. Uji Asumsi Klasik Regresi Linear. Fakultas pertanian Universitas Swadaya Gunung Jati Cirebon. (online). (Email: Zeamays hibrida@yahoo.com. Di akses 17 juli 2013).

Wursanto. 2005. Dasar - Dasar Ilmu organisasi. Cetakan ke - 2. Yogyakarta: CV. Andi Offset.

Wibowo. 2013. Manajemen Kinerja. Cetakan ke - 7. Jakarta: PT. RajaGrafindo Persada.

Wahyu. 13 November 2010. Pengawasan ( online ). ( wahyu410. Wordpress. Com ).

Yosa. 1 juli 2010. Pengertian Pengawasan ( online ) ( itjen-depdagri. go.id / article -25 - pengertian )

Peraturan Bupati Musi Rawas Nomor 12 Tahun 2008 Tentang Pembentukan Unit Pelaksana Teknis Irigasi Musi Rawas Pada Dinas Pekerjaan Umun Pengairan Kabupaten Musi Rawas. 